\title{
A garlic burn
}

\author{
Olivia Sharp, ${ }^{1}$ Saima Waseem, ${ }^{2}$ Kai Yuen Wong ${ }^{3}$
}

${ }^{1}$ Plastic Surgery, Queen Alexandra Hospital, Portsmouth, UK

${ }^{2}$ Plastic Surgery, Guy's and St Thomas' NHS Foundation Trust, London, UK

${ }^{3}$ Plastic Surgery, Oxford University Hospitals NHS Foundation Trust, Oxford, UK

\section{Correspondence to}

Kai Yuen Wong,

kaiyuen.wong@cantab.net

Accepted 18 June 2018

\section{DESCRIPTION}

A 45 -year-old woman presented with a 12 hour history of painful blisters and erythema over the dorsum of her left great toe. The patient reported applying freshly sliced raw garlic to the dorsum of her left great toe during the past 4 weeks for up to 4 hours a day to treat a fungal nail infection.

On examination, the left great toe was swollen, erythematous and blistering. Her great toenail was yellow and slightly lifted from the nail bed. Clinically, she had a partial thickness burn and onychomycosis (figure 1). The skin on the toe was $\mathrm{pH} 9$. The toe was irrigated with water until a normal $\mathrm{pH}$ was reached, and the blisters de-roofed.

Allium sativum (garlic) has been used as a medical treatment for thousands of years across the world. It is said to have antiviral, antibacterial, antifungal, larvacidal and diuretic properties. ${ }^{1}$ Currently, the herb is recommended by naturopathic practitioners to treat a variety of conditions by either ingestion or topical use in its crushed form.

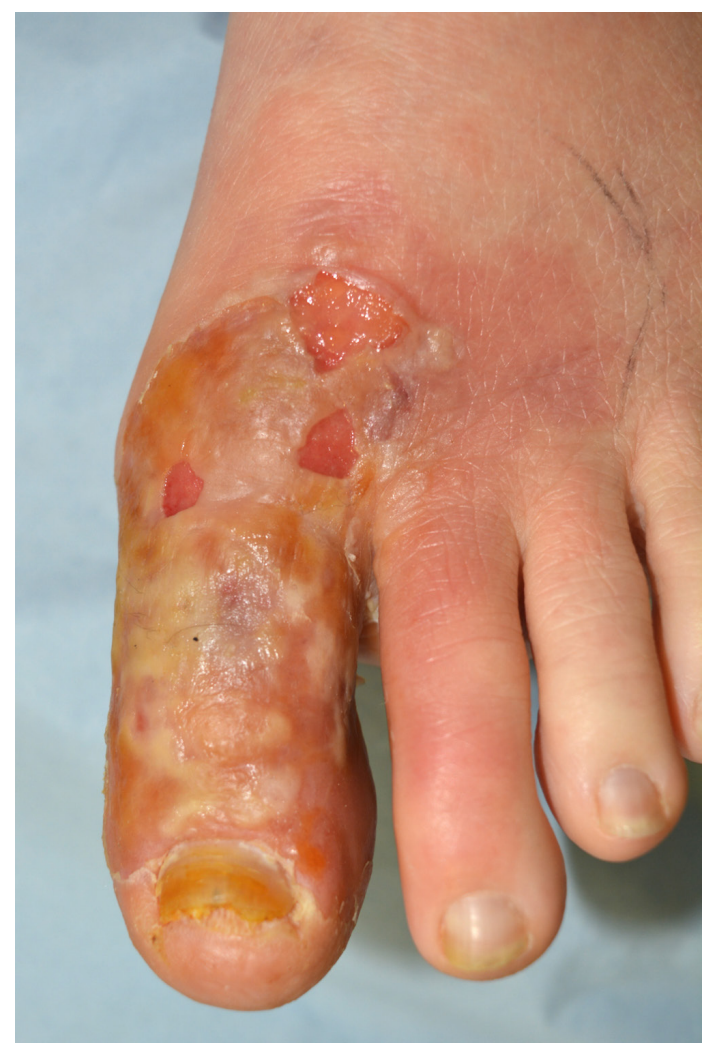

Figure 1 Clinical appearance of garlic burn in this patient. The image shows blistering and erythema consistent with a partial thickness burn. The toenail is discoloured due to the underlying fungal infection.

\section{Learning points}

- This case highlights the diversity in burn aetiology in the general population and the importance of considering somewhat innocuous substances in burn pathogenesis.

- Clinicians should enquire about naturopathic remedies when taking a thorough medical history.

The adverse effects of raw garlic on skin are twofold. It can directly cause a chemical burn, and in sensitised individuals it can provoke a type IV hypersensitivity reaction resulting in contact dermatitis. Sulfur-containing compounds are implicated in these processes, with the main causative compound thought to be diallyl disulfide. ${ }^{2}$

Occupation-related contact dermatitis has been reported by cooks and food handlers, and a case series of self-inflicted garlic burns has also been reported. ${ }^{3}$ Factors affecting severity of the skin burn include quantity and freshness of garlic, duration of exposure, the presence of pre-existing skin conditions and skin sensitivity. ${ }^{2}$

The garlic burn was managed with regular dressings and the skin changes resolved over 2 weeks. Advice on discharge was to avoid further application of garlic or other topical herbal medicines.

This case seeks to highlight the potential for injury following application of garlic-related naturopathic remedies. The general population should be encouraged to apply caution when using such herbal treatments.

Contributors KYW, OS and SW contributed to the planning, concept and design of the paper. SW and OS acquired details of the case and drafted the article. KYW, SW and OS revised the article critically. All authors gave final approval of the version published. The authors are in agreement to be accountable for the article and to ensure that all questions regarding the accuracy or integrity of the article are investigated and resolved.

Funding The authors have not declared a specific grant for this research from any funding agency in the public, commercial or not-for-profit sectors.

Competing interests None declared.

Patient consent Obtained.

Provenance and peer review Not commissioned; externally peer reviewed.

\section{REFERENCES}

1 Baruchin AM, Sagi A, Yoffe B, et al. Garlic burns. Burns 2001;27:781-2.

2 Dietz DM, Varcelotti JR, Stahlfeld KR. Garlic burns: a not-so-rare complication of a naturopathic remedy? Burns 2004;30:612-3.

3 Friedman T, Shalom A, Westreich M. Self-inflicted garlic burns: our experience and literature review. Int J Dermatol 2006;45:1161-3. 
Copyright 2018 BMJ Publishing Group. All rights reserved. For permission to reuse any of this content visit http://group.bmj.com/group/rights-licensing/permissions.

BMJ Case Report Fellows may re-use this article for personal use and teaching without any further permission.

Become a Fellow of BMJ Case Reports today and you can:

- Submit as many cases as you like

- Enjoy fast sympathetic peer review and rapid publication of accepted articles

Access all the published articles

- Re-use any of the published material for personal use and teaching without further permission

For information on Institutional Fellowships contact consortiasales@bmjgroup.com

Visit casereports.bmj.com for more articles like this and to become a Fellow 